\title{
COLONIAL RULE IN NIGERIA: THE AUCHI KINGDOM ENCOUNTER WITH THE BRITISH COLONIALISTS AND THE IMPACTS
}

\author{
Yakubu Suleiman ${ }^{1}$
}

(c) (1)

\section{Introduction}

The closing years of the nineteenth century and the early years of the twentieth century witnessed the establishment of the British colonial rule in Nigeria. There is no gainsaying that the colonization of Nigeria by the British was not an easy task. The British encountered a lot of opposition or resistance from many ethnic groups or polities, while some willingly welcomed the British. The conquest and subjugation of the major ethnic groups or polities has been a common trend with most African historians. But little attention has been given to the minority or small groups like the Auchi Kingdom, in the present day Edo state, Nigeria. In the southern part of Nigeria, great attention has been given to the Benin Kingdom, while little attention has been given to Etsako land, where the Auchi Kingdom is located (Egbefo 20I5, I).

Attention will be focused on the political, socio-economic consequences of colonial rule in the Auchi Kingdom and the significance of these after Nigeria gained independence in I960. Colonial rule left behind a trail of development which had serious implications on the evolutionary development of the Auchi Kingdom into a modern Kingdom. This article is, therefore, aimed at explaining the impact of the innovations of the British on the Auchi Kingdom despite their interior motives and how these innovations impacted on the lives of the people even after the independence of Nigeria in 1960 .

I Department of Historical Sciences, University of Pardubice. Pardubice, Czech Republic. E-mail: susukhaldun@yahoo.com. ORCID: oooo-ooo2-9I84-6460 


\section{Conceptualizing colonialism and imperialism}

Colonialism and imperialism are two concepts that are very similar, but Colonialism is when one country physically exerts complete control over another country and Imperialism is a formal or informal economic and political domination of one country over the other. In a nutshell, colonialism can be thought of as the practice of domination and imperialism as an idea behind the practice. The concept of Colonialism in Africa has a pretty long history; a history that spanned many centuries and phases. In the light of this consideration, the most famous history as far as colonialism is concerned is the European colonization of Africa, which took place between the late I9th and early 2oth centuries (Boardman I973, II4). The African continent was segmented into spheres of influence and colonies of the European powers for the sole purpose of exploitation, subjugation and domination. While the Africans themselves became slaves to the European invaders, the Europeans became masters of the continent and owners of virtually everything in Africa that was of any value (Ozumba and John 2013, 50-5I).

Various schools have written on this forceful subjugation, exploitation and domination of Africa. It was during this period that the reins of exalted traditional government and institution were compulsively seized from African bona fide rulers by the European colonialists who became self-appointed masters. Africans who dared to resist the European infiltration and inhumanity were ruthlessly dealt with. That is to say that some rulers and outstanding African personalities were deposed and exiled or in many cases killed (Mbiti I969, I28). Having overpowered African nations through their sophisticated weapons, the colonialists moved into the second stage of their ambition, namely: humiliation - to divide, rule and exploit the Africans to the maximum. It is on record that this process of humiliation started with the undermining of African cultures and values. And all these set the pace for the underdevelopment of the continent. Rodney $(1972,52-82)$ indicates that the African civilization, culture, beliefs and values were trodden under the feet. For these European invaders to effectively realize their objectives, they had to establish themselves firmly on the continent of Africa by introducing and imposing on Africans their religious, political, economic, social, linguistic and administrative systems, thereby upstaging the hitherto familiar, noble and enviable African institutions.

The concept of Imperialism, on the other hand according to Merriam-Webster (1828), refers to "the policy, practice, or advocacy of extending the power and domination of a nation especially by direct territorial acquisitions 
or by gaining indirect control over the political or economic life of other areas" (Merriam-Webster Dictionary I828). Reill and Wilson (2004) further defined imperialism as "the political, cultural and economic domination of other countries by a nation, achieved through military or other means" (Reill and Wilson 2004, 294). It denotes the domination by one country or people over others (Lenin I999, 8). Even though it has largely been defined by its political and economic interests, imperialism had a civilizational component, which did not simply focus on the acquisition of territories, but the transformation of cultural and religious norms as well (Corrie 2007, 62; Porter 2004, 316; Gorringe 2004, I88). Scholars like Oduro, Pretorius, Nussbaum and Born $(2008,37)$ maintain that colonialism was driven by the "three Cs" - Christianity, Commerce and Civilization. The main idea behind these "Cs" was that all three should go together and promote each other: Christianity must prepare the way for commerce so that Western civilization can replace the African culture, that is, the African 'lack of civilization' (Oduro et al. 2008, 37).

The important thing to note here, perhaps, is that during this colonial period in Africa, some Africans went abroad and studied political science, history, philosophy, law, etc which were tilted towards one direction, namely: the purported "divine" superiority of the whites over the blacks. But these Africans consciously refused to imbibe this kind of dubious intellectual indoctrination and innuendo that they were exposed to. Hence, they all gave different interpretations and considerations to the things they were taught. The point here is that colonialism and imperialism had great significance on Africa: It left a lasting legacy on the African mode of thought, development and civilization.

\section{Methodology}

This article is anchored to the discipline of history. It is worthy to note that oral sources are very important in the reconstruction of African history. Without oral sources, there is no African history. The field work of this article was carried out in various cities in Nigeria. It was really difficult to reach out to the participants to conduct interviews because of the current trend of things and the pandemic situation. The research combines ethnographic and historical designs by using different research techniques such as semi structured, structured and unstructured interviews. Moreover, all the participants participated willingly. Basic demographic information such as age, religion, marital status, occupation, etc were collected from the par- 
ticipants. During the research, we ${ }^{2}$ carried out ten interviews with different respondents. The oral testimonies of these people were very helpful and have gone a long way to prove that the Auchi Kingdom was directly under British colonial rule from 1897 to I960, a period of sixty-three years, when Nigeria gained independence.

Both primary and secondary sources were consulted for the writing of this article. The books that were consulted were very helpful in this regard. This was done in order to have a balanced view of the history of the Auchi Kingdom which provided credibility in its history. Also, during the course of the interview I decided to analyze not only personal narratives but also the attitude, age, behavior and also mindset of all the people interviewed in order to identify discrepancies in their narratives.

\section{Auchi Kingdom before the arrival of the British Colonial Masters}

Auchi is located on latitude 70 north of the Equator and longitude 6.250 east of the Greenwich Meridian. The town is surrounded by a number of Etsako villages and it shares boundary with South Ibie on the East; on the North-East by Jattu; on the North by Ayua, Iyuku and Imehke; on the NorthWest by Ikpeshi and Ihievbe Ogben; on the South by Era and Ayuele-Ugioli (Sule 202I). The topography of Auchi is hilly with valleys and flat plains (Momodu I987, 3). Auchi town is made up of five traditional villages named after the five children of Uchi, the founder of Auchi (Aruna 2006, I). The villages are Utsogu, Akpekpe, Aibotse, Igbhei and Iyekhei. Utsogu is the royal quarter from which the Otaru (King) of Auchi is customarily chosen and enthroned right from the Era of Ikelebe I, in the middle of the nineteenth century (Oseni 1998, 28).

Auchi is one of the fastest developing urban centers in Edo State. It has an estimated population of about I50,000 people (Auchi, wikipedia). The booming commercial activity in the town started long ago. The town was a center for slave trading during the trans-sahara slave trade (Dawood 2020). This equally accounts for the administrative character of the town, as the British colonial government in Nigeria made Auchi the headquarters of local

2 The interviews in Auchi were carried out with the assistance of a close friend, Edagese Alex. We attended the same University in Nigeria. 
administration for the Etsako land after the abolition of slave trade. ${ }^{3}$ Since that time, Auchi has continued to be the headquarters of local of Edo North Senatorial District; the Headquarters of Edo North Police Area Command and of Etsako West Local Government Area; the headquarters for Muslims and center of Islamic learning in Edo State, Nigeria (Seghosime 2006, 2).

Several accounts abound as to the founding of the Auchi Kingdom, but one interesting thing about these accounts is that they are all related in the description they gave about the origin of the town. The town was named after a man called Uchi, who migrated from Udo in the Benin Kingdom about the I4th century before the reign of Oba Ewuare of the Benin Kingdom (Oseni I998, 6I). Another source put it that Auchi is a contraction of the name Evbo-Uchi, meaning "the settlement founded by Uchi" which is the Bini name for 'Usi', meaning "fame", which is associated with nobility in the normal course of native life. ${ }^{4}$ Accordingly, Uchi and his family migrated from Benin and settled in the Guinea Savannah belt of the Etsako land. Uchi left Benin because of the harsh policies of the ruling Oba, incessant wars, intimidation and dehumanization prevalent in the Benin Kingdom which he could not bear (Aruna 2006, I).

This emigration from Benin took place in the fifteenth century. After a very long trek and search for a suitable place to settle, Uchi and his followers settled at a place about I30 kilometers away from the Benin Kingdom on the top of a hill, just behind the present-day Guarantee Trust Bank (Garba 202I). A market developed in and around the location that Uchi and his followers settled. The market is known as "Aku-Uchi" (Uchi Market). The market is still in existence and remains the biggest market in Auchi. Over the years

3 The Auchi Kingdom is known to have experienced growth and development since the $20^{\text {th }}$ century. This is evident in population growth and trading activities. The Auchi Kingdom is also the administrative headquarters of the local council area. It is also the headquarters of all the religious bodies of the area. The Kingdom has five villages which are overseen by chiefs who report to the King of the Kingdom. The villages also are made up of numerous kindreds which are overseen by lesser chiefs who report to the chiefs of the villages. The royal family is from a particular village/quarter known as Utsogu. The king is always chosen from the royal family and the Utsogu quarters. The ascendency to the throne is not hereditary. Any male adult can be chosen from the royal family. See Oseni 1998.

4 There are many versions of the origin of the Auchi Kingdom but the one stated above is the most popular. More information on the origin of the Auchi Kingdom could be sourced from oral sources. The most common source for the reconstruction of African history is oral tradition. The historic incidence of Uchi fleeing from the Benin Kingdom was during a period of chaos, wars and crisis known as "Igodomigodo" in the Bini language. Most kingdoms and settlements in Africa before the $18^{\text {th }}$ century were products of migration as a result of wars, crisis etc. These are major towns and villages that surround the Auchi Kingdom. The Kingdom is known for its central and strategic location. See Aruna 2006. 
after the demise of Uchi, he was deified and a shrine was built on his original abode at Uchi Market. Worshipers of the Uchi deity went to the Uchi shrine with native chalk and salt and made requests, believing strongly in the potency (Charity 202I). The shrine was eventually destroyed and uprooted in an upsurge of the spread of the Islamic religion in the early $20^{\text {th }}$ century (Ornoruan i986, 48).

\section{The arrival of the British Colonial Masters to the Auchi Kingdom}

The Europeans encroached into Africa as slave traders from the 15 th century until the era of colonialism. After the exploitation of Africa through slavery for roughly four hundred years, it was replaced with exploitation through colonialism. Hence, though Europeans ended slave trade, but their interest in Africa remained intact. The Industrial Revolution which started in Britain in the eighteenth century and subsequently in other parts of the world had played a pivotal role in the termination of slave trade and beginning of colonialism. The industrial revolution in Europe accelerated production and this increased the demand for more raw materials and markets. This, in turn, again turned the face of Europeans to Africa to supply both raw materials and new markets for their surplus products. Therefore, colonialism came out of the need of European countries to have direct political control over their colonies so as to ensure the protection of their economic interests (Endalcachew 2015, 23).

The exploitative nature of the colonial economy ensured that very little sustainable development occurred during the colonial period. Neither the profit-mongering European firms nor the stingy colonial government were willing to invest in the long-term development of Nigeria in the period before the Second World War. European firms took their profits back to Europe, enriching shareholders at the expense of exploited Nigerian labor. Because so much of the wealth of Nigeria was being extracted for European profits, very few Nigerians earned enough to invest in local development projects of their own (Falola and Heaton 2008, I2I).

As the main objective of European countries was to satisfy their economic interest, each of them competed to get the biggest and the richest colonies. Consequently, to avoid intra-European war, the colonialists held a conference in Berlin in I884-I885, aiming for a peaceful partitioning of Africa (Thomson 2010, 25). The scramble for Africa at the aforementioned 
conference and other succeeding formations of many small countries in Africa was based on pure imperialist intentions and a voracious quest for wealth (Baah 2003, I). This resulted in arbitrary division of its people without taking into account social cohesion which had kept Africans together for a long period of time..$^{5}$ Africans were not consulted, rather, they were blindly divided to satisfy the selfish interest of the imperialists. Hence, colonialism was primarily intended to exploit the continent and send back profits to the imperialists' home country (Rodney I973, 23I).

It must be said at the Juncture that the Nupe people, who had firm control over the Auchi Kingdom, was a threat to the imperial moves by the British to take over the Auchi Kingdom at the tail end of the eighteenth century (Audu 2020). The British felt that there was a great need to dislodge the Nupe to gain control over the Auchi Kingdom because of its strategic location. The Royal Niger Company was established by the British in I886 and was instrumental in the formation of Colonial Nigeria, as it enabled the British colonialists to establish control over Nigeria for trading relations and administrative purposes (Shaibu 202I).

Sir George Tubman Goldie, who established the Royal Niger Company, epitomized the spirit of the new era of mercantilism and Social Darwinism that was sweeping across West Africa during the global depression. He amalgamated British firms trading on the Lower Niger in 1879 , forming the United African Company (UAC). The monopolistic policies of the UAC, however, impoverished the local palm produce traders, who began to pillage its factories. The UAC then appealed to the Consular Office for military intervention to protect the lives and property of British firms trading on the Niger. Goldie reorganized the UAC and changed its name in I882 to the National African Company (NAC) due to the intrusions of the French on the Niger and in Dahomey and the Germans in Cameroons. He then used his company to undermine the commercial interests of rival foreign firms, undercutting their sales by 24 percent. Goldie further changed the name of the NAC to the Royal Niger Company (RNC) and applied to the British government for

5 This is basically a description of the exploitative tendencies and intentions of the Europeans in Africa The European's intentions and actions were basically profit oriented and this further impoverished the Africans, making them unable to invest in their various communities and this clearly shows that the Europeans used Africa as a place to get all the resources and raw materials that they needed. See (Falola and Heaton 2008). 
a royal charter that would enable him to administer the Niger region. ${ }^{6}$ The charter was granted in I886, and he used the RNC to establish a paramilitary commercial empire on the Niger and the coastal communities (Oriji 2OII, I56).

The Royal Niger Company under the control of Sir George Tubman Goldie ordered his military forces to attack the Nupe Kingdom at Bida, which had emerged as the most powerful Kingdom in the area during that period. It was this military expedition against Bida that led to the withdrawal of all the Nupe soldiers and their war commandants from the Auchi Kingdom and Etsako land as a whole in I897. These troops, like those that were similarly withdrawn from other parts of Nigeria at that time, were to increase the numerical strength of the army in Bida to enable it to put a strong defense against the army of the Royal Niger Company in I897. Despite the strong resistance put up against the British, their Kingdom collapsed due to superior weapons. The British then assumed political administration over the Nupe Kingdom in I897. It is very important to note that the withdrawal of the Nupe troops from the Auchi Kingdom and other communities enabled not just the fall of Bida but also the incursion of the British into the Auchi Kingdom and other communities in $1897 .^{7}$

It must be noted that there are two logical reasons why British occupation of Auchi and other parts of Afenrnai land was conveniently done without resistance from the people. One was the fear envisaged in the consequence of going into military warfare with a more militarily superior power than even their former conqueror, the Nupe. The second, and perhaps much more important reason, was the desire to see to the end of giving out their kinsmen and children as slaves, which had been the main pastime of the Bida government in the area. Thus, in spite of the position which Auchi was already placed during the period of Nupe colonial rule, the coming of the British colonialists was still welcomed as a veritable step to save the people from the yoke of the oppressive Nupe rule.

\footnotetext{
6 Europeans have looked for territories to exercise their military might and dominance over and Africa was the most ideal location. This explains how Europe underdeveloped Africa to develop Europe. See Walter Rodney's book for more information. Also see The Royal Niger Company on wikipedia.

7 The British strategy was to attack and conquer the Nupe Kingdom, the homeland of the Nupe people. The British succeeded in doing so in I897 and this resulted in the establishment of firm imperial rule over the Auchi Kingdom. The year I897 is very significant in Nigerian history because Britain used their military might to conquer major kingdoms in I897. Some of these Kingdoms include the Nupe, Benin, Opopo etc.
} 
The result of this therefore was that by the tail end of 1904, the then Otaru of Auchi, Ikharo Ikelebe, in consultation with his Council of Chiefs, signed the British protection treaty in formal recognition of British colonial rule. ${ }^{8}$ Although it has not been found easy to interpret the full nature of the treaty signed by Otaru Ikharo with the British colonizers, the fact remains that almost all the treaties signed by the British with African rulers were done within the same understanding of the central framework. That is the fact that the contents were hardly understood by African rulers who never realized that they were only signing away their sovereignty through persuasion. But as earlier opined, Otaru Ikharo and members of his council may have foreseen much satisfaction with British protection than giving out their kinsmen and children for slavery to the Bida authorities. Thus, the signing of the British protection treaty by Otaru Ikharo in 1904 consequently led to the dismissal of Bida representatives, Azenis, from Auchi and the formal establishment of British colonial rule in the Kingdom with Idah as its administrative headquarters (Omoruan i986, 1970).

\section{The positive impact of British colonial rule on the Auchi Kingdom}

There are many legacies created and left behind by the British colonial masters that are still very much in existence till the present day. Firstly, the creation of the Auchi Kingdom as the administrative headquarters in Etsako land was done by the British in I920. The collapse of the Nupe Empire in I897 led to the emergence of British colonial rule and administration in all the areas that the Nupe had a strong hold. In January I900, the British proclaimed the Northern and Southern Protectorate. These Protectorates were ruled separately and independently by the British colonial administrators. Under this arrangement the Auchi Kingdom, under Etsako land, was part

8 Britain was ready to remove all obstacles that were on the way from preventing them from establishing imperial control over the Auchi Kingdom and Nigeria as a whole. This made Tubman Goldie to establish and attach a military outfit attached to the Royal Niger Company. This was to ensure that resistant regions were conquered and to firm imperial control was established in such regions. This implies that the British did not want just trading relations, but also wanted firm imperial control over the Auchi Kingdom and beyond. See The Royal Niger Company on wikipedia. 
of the Northern Protectorate and was ruled from Idah, a town located across the River Niger. ${ }^{9}$

The British penetration of Etsako land of which Auchi was to become its headquarters started in 1904, seven years after the defeat of the Emirate of Bida. This date marked the time British imperial patrols moved from their Idah station, then in southern provinces of Nigeria but now part of the present day Kogi state, to Etsako land. When the British arrived at Etsako land, they found the people to be very friendly and accommodating. Etsako land was carved out of Esan District as a separate District.

The British discovered that Ubiaja was too far from Etsako land, so the administrative district was moved to Iddo-Okpella, a town on the far northern part of Etsako land, in that same year, 1904. However, the British did not find the place too suitable for their headquarters. In I9I6, the administrative headquarters was relocated to Fugar, a town on the eastern part of Etsako land. The British, still not satisfied after two years in Fugar, began to search for an ideal location for the siting of their administrative district. Two sites were proposed, Auchi and Ayua, the last is a town located a few kilometers away from Auchi. Auchi was eventually chosen as the new headquarters because of its strategic geographical location at the heart of Etsako land. In I920, the District administrative office was moved to Auchi and Major C. M. Dunn became the first District Officer. ${ }^{\text {IO }}$

The second important thing to note here is that the establishment of British colonial rule in Auchi brought about the introduction of new administrative policies, which like those of the former Nupe overlord and were totally alien to the people. One of such administrative policies was the Indirect Rule system of government which the British colonialists found suitable in this regard. It should be noted that, contrary to what has been shared by some people, the Indirect Rule system was not evolved by the British in recognition of African values but was intended to prefer a solution to inadequate availability of funds and British officials who had been scared by the West

9 The proclamation of the Southern and Northern protectorate and later amalgamation was to aid a more effective administrative control over the two regions with a lesser cost of running the government and the people were not even consulted. This was done to make administration less expensive and easier to carry out due to selfish reasons. See (Adewumi and Egwurube i985).

Io The search for the most ideal location for siting of the headquarters was necessary for them to ensure that an effective administrative system was established. The Auchi Kingdom was chosen because of its central and strategic location. The indirect rule system was intended to cut the cost of administration and save the limited resources. See (Momoh 20I6). 
African hot weather and mosquitoes. Hence the use of the term "white man's burden" to describe the hot region.

Thirdly, there was the creation of a modern official building complex, official staff quarters and a modern prison by Major C. M. Dunn. This was the first time that such had even happened in the Auchi Kingdom. Prior to that time there were no such buildings in the whole of the Auchi Kingdom. All these were done during the time of Major C. M. Dunn, as District officer between I920 and I92I. It may be interesting to note that most of these buildings are still standing till today. Some of them that are still in use have been modified to meet up with the recent standards while others are preserved as historical sites for tourist attraction (Momoh 20I6, II3).

Fourthly, the British introduced Western Education in the Auchi Kingdom. After the exit of Major C. M. Dunn in I92I as District officer, his replacement was an Oxford University trained Lawyer called Barrister Archer. It was Archer's challenge to develop his District educationally and otherwise. The District office was in need of clerks, interpreters and tax collectors and there was no one in Auchi to carry out these roles. He ended up looking for people at Agbede, Okpella and other towns for urgent recruitment. He, accordingly, proceeded to the establishment of the popular Government School in the Auchi Kingdom in 1922. This was the first school to be established in the Auchi Kingdom, which marked the beginning of Western Education in the Auchi Kingdom and then other schools both Primary and Secondary were established in later years.

Again, Barrister Archer embarked on the creation of a network of roads to link up other towns and villages with the District headquarters in the Auchi Kingdom. The Auchi-Ikpeshi road that was started by D. H. Momoh, the then Otaru of Auchi, in I9I9 was taken over by Barrister Archer and extended to Igarra, a town located towards the boundary of the Afemai land in I923. Archer also embarked on the construction of a road to Agenebode through South Ibie, Ekperi. Another road was constructed to link Sabongida Ora through Warrake, Ihievbe and Afuze-Emai. It must be said that many of these roads are still used till the present day. ${ }^{\text {II }}$

II The period when the new official building complex was built, it was regarded as a modern building because there was no building of such at that time. The building is still standing till date. I have visited the building a few times. The establishment of schools in the Auchi Kingdom was a significant event and many people benefited from it. The main reason was to train people that would be used to run the activities and affairs of the District. The establishment of a network of roads within the District was to have easy access to interior villages from the Auchi Kingdom in order to make tax collection easier and to make trading more convenient. See Denton report (1936). 
Furthermore, the Trans-Atlantic slave trade was abolished in the early nineteenth century, but domestic slavery continued. Before the arrival of the Europeans, the Nupe that had established a hegemony over the Auchi Kingdom continued with the practice of slavery and slave trade but the British put an end to this practice when they arrived. In I900, the colonial administration ended the practice of slavery and slave trade within the Auchi Kingdom and beyond, because they believed it was an evil practice and had outlived its essence. This was indeed one of the greatest and most enduring legacies of the British in the Auchi Kingdom and Etsako land (Denton I936).

Additionally, in I92I the colonial administration abolished the practice of trial by ordeal. Archer, the then District officer, was faced with the problem of people being accused of witchcraft, because at that time the people of the Auchi Kingdom had a strong belief in witchcraft and sorcery and this blurred their sense of reasoning. It arose from the ignorance and superstition of the people and it thrived on their poverty. People that were accused of witchcraft were forcefully brought before a shrine where the juju priest administers forces the person to drink a concoction known as "Osaki" which was a poisonous mixture extracted from the bark of trees (Binta 202I). This was boiled with other fetish items and herbs for several days in a clay pot. The poisonous concoction is then administered on the helpless victim. A victim who had a strong immune system survived it and was declared not to be a witch but a victim with a weak immune system who died of the poison was declared a witch. The family of the deceased mourned their loss and continued to live in shame because one of their family members was tagged a witch. ${ }^{12}$

Lastly, in order to achieve justice and fairness, native courts were set up all over the District. These native courts were manned by chiefs who were believed to be men of integrity. The native courts were not given the jurisdiction to hear and determine serious and criminal offenses like arson and murder. Essentially, their civil jurisdiction was restricted to cases related to marital issues, inheritance and minor chieftaincy issues. Serious criminal cases like murder, for example, could only be tried by the superior court based at Idah. The administration of justice in colonial days was short and swift. There was little or no room for tedious legal technicalities. As soon as the facts were carefully and honestly ascertained, the law in its raw form was coldly applied (Omo-Ananigie i936, 98).

I2 See Momoh (20I6) for more details. 


\section{Conclusion}

The situation the British found in the Auchi Kingdom was that of a society still undergoing changes as a result of the Nupe presence. The Nupe, in the wake of their intrusion, introduced novel principles and ideas, to which the people were still getting accustomed to when the British arrived. The origins of some of the characteristic traits of present-day Auchi Kingdom can be traced to this period. In assessing the extent to which the British contact affected the people of the Auchi Kingdom socially, politically, culturally and otherwise, it is important to note that by 1897 when the Nupe no longer had control over the Auchi Kingdom, their administrative innovations persisted. The British colonialists rather built on these administrative innovations to rule over the people successfully. There were some bad practices that were abolished among which includes trial by ordeal and slave trade. There was also the introduction of Western Education and a new means of administering justice. Since colonial rule did not result in the total obliteration of the indigenous practices of the Auchi people, their present-day society still exhibits many of those traits acquired as a result of the Nupe contacts of the late nineteenth century. It must be said at this junction that despite the exploitative tendency of the British they still impacted positively on the Auchi Kingdom.

\section{REFERENCES}

Audu, Oroh (Politician, Former Member of the House of Representative in Nigeria, 65 Years Old, Married, interviewed on 15 August, 2020 at Abuja, Edo State, Nigeria).

Adewumi, J. B. and Joseph Egwurube. "The Roles of Traditional Rulers in Local Government: Historical Perspective in Aborisade O.” (Ed.) Local Government and Traditional Rulers in Nigeria. Ile-Ife: Unife Press.

"Government in Historical Perspective". In Local Government and the Traditional Rulers in Nigeria edited by Oladimeji Aborisade. Nigeria: University of Ife Press.

Arunah, Abdulrahman. O. 2006. A History of Auchi Kingdom. Ilorin: Haytee, Press and Publishing Com. Nig Ltd.

Baah, Anthony. 2003. "History of African Development Initiatives." Johannesburg: Africa Labor Research Network Workshop, 22-23.

Binta, Fatima Yakubu (Tailor, Housewife and Mother, 7I Years Old, Widow, interviewed on 17 March, 2021 at Auchi, Edo State, Nigeria). 
Boardman, John. I973. The Greeks Overseas. Harmondsworth: Penguine Books.

Charity, Momoh (Civil Servant, 48 Years Old, Married, interviewed on 19 March, 2021 at Auchi, Edo State, Nigeria).

Corrie, J. 2007. Dictionary of Mission Theology - Evangelical Foundations. Nottingham: Inter-Varsity Press.

Dawood, Omolumen. Egbefo (Professor of History and Researcher, 58 Years Old, Married, interviewed on 16 October, 2020, at Iyhamo, Edo State, Nigeria).

Denton, N. 1936. A Political Intelligence Report on the Etsako Clans of the Kukuruku Division. Nigeria: National Archives, Ibadan.

Egbefo, Dawud, O. 2015, "Resistance to Colonial in Nigeria: Esanland Encounter with the British Colonialists and its Effects on Intra-Inter-Group Relations". Academic Horizon, A Journal of the School of Postgraduate Studies I, no. I. https://www.researchgate.net/publication/323392988_Resistance_to_Colonial_in_Nigeria_Esanland_ Encounter_with_the_British_Colonialists_and_its_Effects_on_ Intra-Inter-Group_Relations

Endalcachew Bayeh. 20I5. "The Legacy of Colonialism in the Contemporary Africa: A case for intrastate and interstate conflicts". International Journal of Innovative and Applied Research 3, no. 2. ISSN 2348 - 0319.

Erhagbe, Eddy, O. I982. Etsako land in Transition, I860-I948: An Analysis of Change in An Indigenous Nigerian Society (unpublished), MA Dissertation, Department of History, University of Benin, Nigeria.

Falola, T and Heaton, M. M. 2008. A History of Nigeria. Cambridge: University of Cambridge Press.

Garba, S. Zibril, (Politician, 62 Years Old, Married, interviewed on 29 march, 2021, at Auchi, Edo State, Nigeria).

Gorringe, T. J. 2004. Furthering Humanity: A Theology of Culture. Aldershot: Ashgate Publishing.

Lenin, V. I. I999. Imperialism: The Highest Stage of Capitalism. Sydney: Resistance Books.

Merriam-Webster Dictionary. I828. Imperialism | Definition of imperialism. Available at: https://www.merriam-webster.com/dictionary/ imperialism 
Momodu, A. O. I987. The Role of Otaru Momoh in the Islamization of Auchi and its Environs, (unpublished) a B.A. Long Essay Submitted to the Department of Religions, University of Ilorin.

Momoh, Robson. 2016. New perspectives on the history and politics of Nigeria: The Etsako Experience. Edo: Afenmai Grafix.

Mbiti, John S. 1969. African Religions and Philosophy. London: Heinemann Books.

Obomeighei, Wajeed (Journalist and writer, 54 Years Old, Married, interview on 24 August, 2020 at Abuja, Nigeria).

Oduro, T., Pretorius, H., Nussbaum, S. \& Born, Bryan. 2008. Mission in an African Way: A Practical Introduction to African Instituted Churches and their Sense of Mission. South Africa: Christian Literature Fund and Bible Media Publication.

Omoruan, J. O. B. I986, “The Planting of Islam in Afenmai land: Ihievbe, A case Study" (unpublished) B. A. (Hons) Long Essay, Department of History, University of Ilorin, Ilorin, Nigeria, I986.

Oseni, Zakariyav Idrees-Oboh (Professor of Arabic and Islamic Studies and Researcher, 7I Years Old, interviewed on 19 July, 2020 at Ilorin, Kwara State, Nigeria).

Oseni, Zakariyav. I. I998. "The Islamization of Auchi Kingdom in South Central Nigeria" A paper presented at the First Auchi Day celebration in the Auchi Kingdom, Lagos, https://www.researchgate.net/ publication/337I99323_Traditional_Humano-Communal_Ethics_ In_Inter-Faith_Relations_The_Etsako_Edo_Experience

Oriji, J, N. 20II. A Political Organization in Nigeria since the late stone age. New York: Palgrave Macmillan.

Ozumba, Godfrey. O. and John, Elijah. O, (eds). 20I2. African Political Philosophy. Uyo: El-Johns Publishers, 45-79.

Reill, P. H. \& Wilson, E. J. 2004. Encyclopedia of the Enlightenment. New York: Facts on File, Incorporated.

Rodney, Walter. I973. How Europe Underdeveloped Africa. London: Bogle-L'Ouverture Publications.

Seghosime, K. M. 20II. Origin and Development of Auchi. Auchi: Smilestal Global Digital.

Shaibu, Saliu, (Civil Servant, 50 years Old, interview on 24 March, 2021 at Edo State, Nigeria).

Stanfield, D. I937. Intelligence Report on the Aviele Clan, Ibadan, NAI, I937. 
Sule Richard Expomah, (Civilian Servant, 59 Years Old, interview on 30 March, 2021 at Edo State, Nigeria).

Thomson, Alex. 20I0. An Introduction to African Politics, Third Edition. London, Routledge.

Thomas Nelson. 20I8. West African Secondary School Atlas. Ikeja: New Edition, https://wasscehistorytextbook.com/

Tony, Momoh (Journalist, Lawyer and Former Federal Minister of Information in Nigeria, 8I Years Old, interviewed on 22 July, 2020 at Lagos State, Nigeria).

Wikipedia. 2020. From Wikipedia, the free encyclopedia, “Auchi”, edited on 25th September 2020, https://en.wikipedia.org/wiki/Auchi

Wikipedia. 2020. From Wikipedia, the free encyclopedia, "Royal Niger Company," edited $7^{\text {th }}$ November, 2020, https://en.wikipedia.org/ wiki/Royal_Niger Company.

\section{ABSTRACT}

The British conquest of parts of Africa in the nineteenth century has attracted a lot of studies. Yet, all scholars involved hold different views, especially as to the role of the indigenous African groups in it. There are those who opine that the Africans who resisted the British were patriotic in spite of the futility of their actions, and the Africans who supported the British are portrayed as collaborators or saboteurs that facilitated imperialism. Other scholars are of the opinion that those who took sides with the British were not necessarily collaborators or unpatriotic elements, but that they merely reacted to the circumstances of the time. The incursion of the British to the Auchi Kingdom was part of their general conquest and occupation of Nigeria which was sequel to the collapse of the Nupe imperial control of the Auchi Kingdom in I897. This was a deliberate act by which the British sought to guarantee their interest in the South West of the Niger. The intention of this paper therefore is to examine the British colonial rule in the Auchi Kingdom. Attention would be paid to the impact of the British colonial rule in the Auchi Kingdom amidst their exploitative intentions. The paper adopts both primary and secondary sources in its analysis. The paper then concludes that despite the exploitative intentions of the British, they still impacted positively on the Auchi Kingdom, unlike the Nupe that enslaved the Auchi people. As the saying goes "Every cloud has a silver lining".

\section{KEYWORDS:}

Colonialism. Imperialism. Innovations. Kingdom. British. 